\title{
Hydroclimatic variations reveal differences in carbon capture in two concurrent conifers in northern Mexico
}

\author{
Marcos González-Cásares ${ }^{1,2}$, Marín Pompa-García ${ }^{1}$, Alejandro Venegas-González ${ }^{\text {Corresp., }}{ }^{3}$, Pedro Domínguez-Calleros \\ ${ }^{1}$, José Hernández-Díaz ${ }^{4}$, Artemio Carrillo-Parra ${ }^{4}$, Marco González-Tagle ${ }^{5}$ \\ ${ }^{1}$ Facultad de Ciencias Forestales, Universidad Juárez del Estado de Durango, Durango, México \\ 2 Programa Institucional de Doctorado en Ciencias Agropecuarias y Forestales, Universidad Juárez del Estado de Durango, Durango, México \\ 3 Centro de Observación de la Tierra-Hémera/ Escuela de Ingeniería Forestal/Facultad de Ciencias, Universidad Mayor, Santiago, Chile \\ 4 Instituto de Silvicultura e Industria de la Madera, Universidad Juárez del Estado de Durango, Durango, México \\ 5 Facultad de Ciencias Forestales, Universidad Autónoma de Nuevo León, Nuevo León, México \\ Corresponding Author: Alejandro Venegas-González \\ Email address: alejandro.venegas@umayor.cl
}

Background. Forest ecosystems are considered among the largest terrestrial carbon sinks. The dynamics of forest carbon depend on where the carbon is stored and its responses to environmental factors, as well as the physiology of the trees. Thus, threatened forest regions with high biodiversity have great scientific importance, such as the Sierra Madre Occidental in Mexico. A comparative analysis of tree species can expand the knowledge of the carbon cycle dynamics and ecological processes in this region. Here, we examined the growth, wood density, and carbon accumulation of two threatened species (Pseudotsuga menziesii and Cupressus lusitanica) to evaluate their hydroclimatic responsiveness.

Methods. The temporal variations in the carbon accumulation patterns of two co-occurring species ( $P$. menziesii and $C$. lusitanica) and their sensitivity to the local climate were studied using dendroecological techniques, X-ray densitometry, and allometric equations.

Results. The results show that the annual carbon accumulation in $C$. lusitanica is positively associated with the temperature during the current fall, while the carbon accumulation in $P$. menziesii is correlated with the rainfall during the winter of the previous year. The climatic responses are associated with the intra-annual variations of wood density and ring widths for each species. The ring width was strongly correlated with carbon accumulation in C. Iusitanica, while the mean wood density was linked to carbon accumulation in P. menziesii.

Discussion. This study has implications for the carbon accumulation rates of both species, revealing differences in the carbon capture patterns in response to climatic variations. Although the species coexist, there are variation in the hydroclimatic sensitivity of the annual carbon sequestered by trunks of trees, which would be associated with tree-ring width and/or wood density, i.e. directly by anatomical features. The results are relevant to analyze the response to the variability of climatic conditions expected in the near future of the tree communities of Sierra Madre Occidental. Therefore, this study provides a basis for modeling the long-term carbon budget projections in terrestrial ecosystems in northern Mexico. 


\section{$1 \quad$ Hydroclimatic Variations Reveal Differences in Carbon}

\section{Capture in Two Concurrent Conifers in Northern Mexico}

4 Marcos González-Cásares ${ }^{1,2}$, Marín Pompa-García ${ }^{2}$, Alejandro Venegas-González ${ }^{3}$, Pedro 5 Domínguez-Calleros ${ }^{2}$, José Hernández-Díaz ${ }^{4}$, Artemio Carrillo-Parra ${ }^{4}$, Marco González-Tagle 5.

$6{ }^{1}$ Programa Institucional de Doctorado en Ciencias Agropecuarias y Forestales, Universidad Juárez 7 del Estado de Durango, Durango, México.

$8 \quad{ }^{2}$ Facultad de Ciencias Forestales - Universidad Juárez del Estado de Durango. Durango, México.

93 Centro de Observación de la Tierra-Hémera, Escuela de Ingeniería Forestal, Facultad de 10 Ciencias, Universidad Mayor, Santiago, Chile.

$11^{4}$ Instituto de Silvicultura e Industria de la Madera, Universidad Juárez del Estado de Durango, 12 Durango, México

$13{ }^{5}$ Facultad de Ciencias Forestales - Universidad Autónoma de Nuevo León. Nuevo León, México.

16 Corresponding Author: Alejandro Venegas-González ${ }^{3}$, Centro de Observación de la Tierra-

17 Hémera, Escuela de Ingeniería Forestal, Facultad de Ciencias, Universidad Mayor 8580745,

18 Santiago, Chile

19 alejandro.venegas@umayor.cl 
20 Abstract

21 Background. Forest ecosystems are considered among the largest terrestrial carbon sinks. The 22 dynamics of forest carbon depend on where the carbon is stored and its responses to environmental

23 factors, as well as the physiology of the trees. Thus, threatened forest regions with high biodiversity 24 have great scientific importance, such as the Sierra Madre Occidental in Mexico. A comparative 25 analysis of tree species can expand the knowledge of the carbon cycle dynamics and ecological 26 processes in this region. Here, we examined the growth, wood density, and carbon accumulation 27 of two threatened species (Pseudotsuga menziesii and Cupressus lusitanica) to evaluate their 28 hydroclimatic responsiveness.

Methods. The temporal variations in the carbon accumulation patterns of two co-occurring species (P. menziesii and C. lusitanica) and their sensitivity to the local climate were studied using dendroecological techniques, X-ray densitometry, and allometric equations.

Results. The results show that the annual carbon accumulation in $C$. lusitanica is positively associated with the temperature during the current fall, while the carbon accumulation in $P$. menziesii is correlated with the rainfall during the winter of the previous year. The climatic responses are associated with the intra-annual variations of wood density and ring widths for each species. The ring width was strongly correlated with carbon accumulation in C. lusitanica, while the mean wood density was linked to carbon accumulation in P. menziesii.

Discussion. This study has implications for the carbon accumulation rates of both species, revealing differences in the carbon capture patterns in response to climatic variations. Although the species coexist, there are variation in the hydroclimatic sensitivity of the annual carbon sequestered by trunks of trees, which would be associated with tree-ring width and/or wood density, i.e. directly by anatomical features. The results are relevant to analyze the response to the variability of climatic conditions expected in the near future of the tree communities of Sierra Madre Occidental. Therefore, this study provides a basis for modeling the long-term carbon budget projections in terrestrial ecosystems in northern Mexico.

\section{Introduction}


Many of the world's forest ecosystems are negatively responding to climate change, including changes in biodiversity, high mortality of tree communities, and increases in plagues and diseases (Allen et al., 2010). These phenomena are related mainly to the global increase in the intensity and severity of mega droughts in many regions, which have caused an acceleration in foliar senescence and forest decline in many tree species (Bigler et al., 2007; Sánchez-Salguero, 2010; Zeppel, Anderegg \& Adams, 2012; Périé \& De Blois, 2016; Venegas-González et al., 2018).

Tree growth in forest ecosystems is the most important terrestrial process associated with carbon dynamics. The total terrestrial carbon sink by forests is currently estimated at $2.4 \pm 0.4 \mathrm{PgC}$ per year (global net sink $=1.1 \pm 0.8 \mathrm{PgC}$ per year), being the temperate forests the second most important sink after tropical forest (Pan et al. 2011). However, the sequestration carbon by forest ecosystem depend on different factors, such as extreme weather events, land use change, stand age, forest disturbances, management practices and competition, among other ecological processes (IPCC, 2013). Thus, tree-ring growth dynamics contribute to the understanding of annual carbon uptake in forest ecosystems, allowing proposal of management actions for mitigation and adaptation to climate change ( Babst et al., 2014a ). forests represent the largest terrestrial oxygen- and biomass-producing ecosystems that remain in southwestern North America (González-Elizondo et al., 2012). The great biodiversity of this region allows for studies of concurrent species of great ecological importance, such as Cupressus lusitanica (Mill.), which grows in areas with high water availability, and Pseudotsuga menziesii (Mirb.) Franco, which represents a southern populations, with a limited distribution in Mexico. reconstructions (e.g. Acosta-Hernández et al., 2017). Some studies have been conducted with the 
74 intent to reconstruct precipitation (Cleaveland et al., 2003, Villanueva et al., 2011), teleconnections

75 with El Niño-Southern Oscillation (Cleaveland et al., 2003), drought occurrence (Cerano et al.,

76 2011), evaporation data (Pompa-García \& Camarero, 2015), and analyze the seasonal climatic

77 variations through early and latewood (Carlón-Allende et al., 2018). Tree-ring analyses (associated

78 with other methods) have proven that the accumulation of carbon in different species (Pinus

79 arizonica and Pinus cembroides) can be influenced by specific hydroclimatic conditions, site

80 conditions, or the functional characteristics of each species (Pompa-García et al., 2018). However,

81 this information is unknown in some threatened species of the Sierra Madre Occidental, such as

82 Cupressus lusitanica and Pseudotsuga menziesii. As a result of their distributions along

83 biogeographic gradients, these concurrent species can be used to evaluate the effects of limited

84 water resources and the different conservation statuses on their growth dynamics, wood density,

85 and carbon accumulation, as well as to assess the influence of hydroclimatic variability.

Several methods are used to estimate carbon content, such as total organic carbon (TOC;

87 Houghton, 2005), X-ray densitometry (Taki et al., 2014; Pompa-García \& Venegas-González, 88 2016), and allometric equations based on time series of tree diameters (Návar, 2009). These

89 nondestructive methods can be used to analyze the temporal variations in carbon fixation of trees

90 (Pompa-García et al., 2018).

91 In general, biomass evaluations assume that wood density is constant, ignoring the 92 interannual variation caused by the climate and tree age (Babst et al., 2014b). The calculation of 93 tree biomass can be obtained as a product of the volume and density of the wood. Current biometric 94 studies rely on stem diameter growth estimated from tree rings (Babst et al., 2014b).

As tree growth responds differently to environmental conditions across tree species in

96 Sierra Madre Occidental (Pompa-García et al., 2017a), there will also be variation in the total 
97 carbon accumulation by species. We used tree rings, allometric equations and wood density (WD)

98 to examine the growth and carbon accumulation of C. lusitanica and P. menziesii trees located in

99 the Sierra Madre Occidental and to evaluate their hydroclimatic response. We hypothesized that

100 the variations in carbon accumulation reflect climatic conditions, according to the specific

101 sensitivity of each species.

102

103

2. Materials and Methods

104

2.1. Area of Study

105 The study was conducted in the Sierra Madre Occidental, in the state of Durango, northwestern

106 Mexico (Figure 1). This mountainous system of volcanic origin has an average elevation of 2000

107 masl, reaching 3000 masl in some areas, and it extends from the south of the Tropic of Cancer to

108 the west of Durango, ending in southern Arizona (Aguirre-Díaz \& Labarthe-Hernández, 2003).

109 Figure 1. Study site location and local climate diagram. (a) The map shows the study area where 110 Cupressus lusitanica and Pseudotsuga menziesii trees were sampled. (b,c) The climate diagrams 111 illustrate the distribution of monthly precipitation $(\mathrm{P})$ and mean temperature $(\mathrm{T})$ for 1946-2015

112 (El Salto meteorological station; located $10 \mathrm{~km}$ from the study site, at coordinates $23^{\circ} 41^{\prime} 25^{\prime \prime}$, $113105^{\circ} 21^{\prime} 10^{\prime \prime}$, at an altitude of 2,538 m).

114

This region has a temperate subhumid climate with a wet and cool summer due to the

116 influence of the North American Monsoon (NAM). The region also has two characteristic dry

117 seasons during spring and winter. The precipitation ranges from 1000 to $1200 \mathrm{~mm}$ annually. The

118 main rainy season begins with the start of the NAM in late June or early July and ends in late

119 September. Further low-intensity precipitation falls during the cold season (November-February).

120 The maximum values of monthly temperatures occur from May to June; with minimum mean

121 temperature of $7{ }^{\circ} \mathrm{C}$, and a maximum mean temperature of $17^{\circ} \mathrm{C}(\mathrm{CNA}, 2016)$. The dominant soils 
122 in the area are cambisols, lithosols, regosols, and phaeozems (Aguirre-Díaz \& Labarthe-

123 Hernández, 2003), while in the study sites, we found mainly luvisol, regosol and cambisol.

\section{2.2. Study Species and Sampling}

125 We selected two coniferous species from Sierra Madre Occidental, Cupressus lusitanica and 126 Pseudotsuga menziesii, due to their dendrochronological potential and importance for 127 conservation and management (e.g. Pompa-García, Sánchez-Salguero \& Camarero, 2017).). C. 128 lusitanica is located in humid sites while that $P$. menziesii is found in semihumid sites. Fifteen

129 dominant individuals of each species were selected and sampled (diameter $\geq 10 \mathrm{~cm}$ at breast height 130 (DBH), approximately $1.30 \mathrm{~m}$ above ground level). From each of these trees, two radial growth 131 cores were collected at a height of $1.3 \mathrm{~m}$ with a nondestructive method using a Pressler borer $(\varnothing$

$132=5.1 \mathrm{~mm})$. P. menziesii was collected at 2,747 masl and shows an average DBH and height of $13336.3 \mathrm{~cm}$ and $18.1 \mathrm{~m}$, respectively. C. lusitanica was collected at 2,651 masl and shows an average

$134 \mathrm{DBH}$ and height of $31.5 \mathrm{~cm}$ and $16.4 \mathrm{~m}$, respectively (Table 1). The field permit approval was 135 granted by the Mexican Federal Government agency SEMARNAT (i.e. Secretariat of Environment 136 and Natural Resources, N SGPA/DGVS 09456/16).

\section{2.3. Annual Density of Wood}

138 Radial wood cores were cut in the transverse direction, maintaining a thickness of $1.7 \pm 0.2 \mathrm{~mm}$, 139 and these cores were kept in a room temperature $\left(20^{\circ} \mathrm{C}\right)$ and $50 \%$ relative humidity until they 140 reached a stable moisture content of $12 \%$ (Tomazello et al., 2008). To determine the ring widths 141 and wood densities, the samples were scanned from bark to pith using an X-ray densitometer 142 QTRS01X Tree-Ring Scanner (Quintek Measurement Systems, Knoxville, TN, USA) at $0.08 \mathrm{~mm}$

143 intervals. The demarcation zone between the rings was automatically configured by the device and 144 checked manually for each ring that was analyzed. For each year, the ring width (RW), mean wood 
145 density (MeanD), maximum wood density (MXD), and minimum wood density (MND) were

146 determined. These four variables were used to analyze the response to local climate variability.

147 The MeanD value was used to estimate the increase in aerial biomass and carbon.

148 2.4. Development of Chronologies

149 We developed chronologies using the ring width obtained from the X-ray densitometer. Visual

150 dating was then statistically validated by using the COFECHA program, which compares each

151 series with a master chronology for each species (Holmes, 1983). For the construction of

152 chronologies, the natural long-term growth trends (age and tree geometry) were eliminated using

153 a negative exponential function to obtain standardized ring widths. Subsequently, an

154 autoregressive model was applied to each of the standardized series to eliminate most of the

155 temporal autocorrelation related to the growth of the previous year. Finally, a robust biweight

156 average was used to obtain the chronologies of the residual indices for each species $($ mean $=1)$.

157 This procedure was performed using the dendrochronology program library in R (dplR; Bunn,

158 2008) of the free statistical software R (R Development Core Team, 2015).

159 2.5. Aerial Biomass and Carbon Estimation

160 The annual RW values were used to reconstruct the historical diameters of the trees and their

161 increases in basal area. These values were then combined with the MeanD values to estimate

162 biomass and, subsequently, the carbon allocated in that particular year. To estimate the biomass,

163 we used the following allometric equation (1), which was proposed to estimate the carbon stocks

164 in the forests of northwestern Mexico (Návar, 2009):

165

$$
\mathrm{AWB}=0.0752 * D^{2.4448} * 2.0331^{p}
$$

166 where $\mathrm{AWB}=$ aerial biomass; $\mathrm{D}=$ normal diameter; and $\mathrm{p}=$ wood density. Different percentages 
167 of carbon concentrations in the biomass were used according to specific laboratory analyses

168 (Yerena-Yamallel et al., 2012), as follows: C. lusitanica, 45.57\%, and P. menziesii, 47.78\%

169 (Pompa-García et al., 2017b).

170 2.6. Statistical Analyses

171 Statistical analyses were performed using the Mann-Whitney-Wilcoxon test, with $\mathrm{p}<0.05$

172 considered significant in the evaluation of differences in radial growth, density, and carbon

173 accumulation between species. This nonparametric test was used because the values of the

174 variables did not comply with the basic assumptions of a normal distribution, according to a

175 Shapiro-Wilks test (Zar, 2010).

176 The influences of climate (precipitation and temperature) on RW and WD were evaluated by

177 analyzing the Pearson correlation coefficients, which were estimated for each species using

178 residual chronologies. Autoregressive models were used to eliminate any temporal autocorrelation

179 (Cook, 1985). Chronologies were compared with parameters of local climatic variability:

180 Maximum temperature (Tmax), minimum temperature (Tmin), average temperature (Tmean), and

181 precipitation $(\mathrm{Pp})$. In addition, we evaluated the relationship between carbon accumulation and

182 internal variables (RW and WD) and climatic influences (precipitation and temperature) by

183 principal component analysis. Climatic data sets (1946-2014) were obtained from the "El Salto"

184 meteorological station, located at coordinates $23^{\circ} 41^{\prime} 25^{\prime \prime},-105^{\circ} 21^{\prime} 10^{\prime \prime}$, which is less than $10 \mathrm{~km}$

185 from the study site at an altitude of 2,538 m (CNA, 2016).

\section{3. Results}

187 3.1. Growth, Density and Carbon Accumulation 
188 Table 1 shows the descriptive statistics of RW, density, and carbon accumulation for both tree

189 species that were analyzed. The lengths of the chronologies, which included at least five trees,

190 ranged from 113 (P. menziesii) to 159 (C. lusitanica) years, and the longest chronologies (with

191 less than five trees) were those of $C$. lusitanica (244 years). The values of the expressed population

192 signal (EPS) for P. menziesii were $\geq 0.85$ over the entire period (estimated with at least five trees),

193 mainly since 1920, showing that replication of the sampling was adequate. In the case of $C$.

194 lusitanica, the usual EPS threshold of 0.85 was not reached (EPS $=0.78)$, but this does not mean

195 that the samples were not adequately cross-dated. Rather, this means that the climate signal is

196 lower in comparison to the sites where Pseudotsuga menziesii thrives (Wigley, Briffa \& Jones,

197 1984). This sampling strategy has yielded good results for quantifying carbon accumulation

198 through tree rings (Pompa-García et al., 2018). In this sense, before 1920, higher variability in the

199 ring width series was observed (Figure 2). The mean sensitivity was 0.25 for both species, showing

200 that the trees react to the environment through their annual growth variability (Grissino-Mayer, $2012001)$.

202 Table 1. Descriptive statistics of chronologies. Time span (TS), mean sensitivity (MS), expressed 203 signal of the population (EPS), density (WD), carbon accumulation (C).

204 Figure 2. Tree-ring chronologies of the two study species. Residual chronologies (black lines) and 205 series (gray lines) of ring widths of the two study species for the best cross-dated period. (a) 206 Cupressus lusitanica, (b) Pseudotsuga menziesii.

210 In general, there was variation in the wood density measured since 1920, especially in P. menziesii

211 (Figure 3), where the three variables (maximum, minimum, and mean) exhibited negative trends. 
212 In contrast, $C$. lusitanica trees showed positive trends in mean wood density (MeanD) and

213 minimum wood density (MND).

214

215 Figure 3. Mean values of wood density of the two study species. Mean $\pm \mathrm{SE}$ values of maximum 216 density (MXD), minimum density (MND), and mean density (MeanD) of the two study species,

217 for the period 1920-2014 (five trees per species). Positive (+) and negative (-) trends of density 218 values are shown in right graphics. (a,b) Cupressus lusitanica, (c,d) Pseudotsuga menziesii.

\subsection{Climatic Influence on Radial Growth and Wood Density}

221

222

223

224

225

226

227

228

229

230

231

232

233

234

The influences of climate variables on the RW and the WD variables (MND, MXD and MeanD) are shown in Figures 4 and 5 for the period 1946-2014. Overall, P. menziesii showed more climatic sensitivity than $C$. lusitanica. For accumulated precipitation, the RW of $P$. menziesii trees was positively correlated with the rainfall during the winter or cold season (from October to April, $r=$ $0.60, p<0.001$ ), while MND and MeanD exhibited negative correlations with the rainfall during winter and spring (from December to May, $\mathrm{r}<-0.36, \mathrm{p}<0.01$ ). For $C$. lusitanica, the general pattern was that all the variables negatively reacted to the increase in rainfall during all months, with the change in MXD being significant throughout the year $(\mathrm{r}<-0.26, \mathrm{p}<0.05)$ (Figure 4). Regarding the mean temperature, the RW and MXD of $P$. menziesii trees showed negative correlations with temperature during the previous and current growth years, which were significant for spring (March to May, $\mathrm{r}<-0.35, \mathrm{p}<0.01)$ and for annual mean temperature $(\mathrm{r}<-0.30, \mathrm{p}<0.05)$ in relation to RW, as well as for the temperature of the previous fall (September to November, $\mathrm{r}<-0.35$, $\mathrm{p}<0.01$ ) related to MXD. For $C$. lusitanica, we observed a positive association between MND and MeanD and the mean temperature of the previous and current fall $(\mathrm{r}<-0.32, \mathrm{p}<0.01)$ (Figure 5). 
235 Figure 4. Relationships between residual chronologies (growth ring width (RW), maximum 236 density (MXD), minimum density (MND), and mean density (MeanD) and accumulated 237 precipitation. The left and right columns represent the analysis by month and by season, 238 respectively; that is, summer, fall, winter, spring, annual, and cold (October-April). Letters 239 indicate growth periods ( $\mathrm{PY}$ and lowercase $=$ previous year, $\mathrm{CY}$ and uppercase $=$ current year). 240 Dashed horizontal lines indicate statistical significance at the 95\% confidence level. (a) Cupressus 241 lusitanica, (b) Pseudotsuga menziesii.

242

243

244

245

246

247

248

249

250

251

252

253

254

255

256

257

258

259

260

261

262

Figure 5. Relationships between residual chronologies (growth ring width (RW), maximum density (MXD), minimum density (MND), and mean wood density (MeanD) and mean temperature. The left and right columns represent analysis by month and by season, respectively; that is, summer, fall, winter, spring, annual, and cold (October-April). Letters indicate growth periods $(\mathrm{PY}$ and lowercase $=$ previous year, $\mathrm{CY}$ and uppercase $=$ current year $)$. Dashed horizontal lines indicate statistical significance at the $95 \%$ confidence level. (a) Cupressus lusitanica, (b) Pseudotsuga menziesii.

\subsection{Local and Climatic Influence in Carbon Accumulation}

The annual carbon accumulation for 1920-2014 is represented in Figure 6, which shows a higher carbon accumulation in P. menziesii trees $\left(3.7 \mathrm{~kg} \mathrm{yr}^{-1}\right)$ than in C. lusitanica $\left(2.2 \mathrm{~kg} \mathrm{yr}^{-1}\right)$ (Table 1). Since 1975, an increase in carbon accumulation in P. menziesii but a decrease in C. lusitanica (which has recovered since 2005) has been observed (Figure 6a). This difference could be explained by the climatic influences (temperature and precipitation) and internal influences (radial growth and wood densities). These results seem to correspond to the high correlation between carbon and mean wood density of the first species $(r=0.48, p<0.01)$ (Figure $6 b)$ and carbon and ring width in the second species $(r=0.45, \mathrm{p}<0.01)$ (Figure 6c). Regarding climatic influences, we observed that carbon accumulation in C. lusitanica is linked to the temperature of the fall season $(\mathrm{r}=0.40, \mathrm{p}=0.02)$, while carbon accumulation in $P$. menziesii is strongly associated with the precipitation during the previous winter $(\mathrm{r}=0.58, \mathrm{p}=0.0002)$ (Figure 7).

Figure 6. Temporal variation of carbon capture. (a) Carbon accumulation per year in the two studied conifers. Gray lines indicate the standard error. (b) Relationship between carbon 
265 accumulation per year and ring width in Cupressus lusitanica. (c) Relationship between carbon 266 accumulation per year and mean wood density in Pseudotsuga Menziesii. (d) Data trend of mean 267 annual temperature and total precipitation per year

Figure 7. Principal component analysis between carbon capture and internal influences (radial growth and wood density variables) and seasonal climatic influences (precipitation and temperature) for 1975-2014. The yellow, green, blue and red circles indicate radial growth, the wood density variables, the precipitation variables, and the temperature variables, respectively. Win $=$ winter, Fall $=$ autumn, $\mathrm{Spr}=$ spring, Sum $=$ summer. The dashed circle represents the maximum correlation with carbon accumulation. (a) Cupressus lusitanica (cophenetic correlation = 0.79), (b) Pseudotsuga menziesii (cophenetic correlation $=0.81$ ).

276

277

\section{Discussion}

278

279

280

281

282

283

284

285

286

287

288

289

290

The dendrochronological statistics were adequate for P. menziesii; however, C. lusitanica had a low EPS (0.78; Wigley, Briffa \& Jones, 1984), which is consistent with previous studies carried out in the study area (Pompa-García et al., 2017a). This result is attributed to the fact that $C$. lusitanica is considered a species with low sensitivity to climatic variability because it inhabits areas near water bodies; however, it also responded to local climatic variability (Figures 4, 5 and 7). The results indicate a strong relationship between the internal variables (RW and WD) and external factors (climatic variables) in the carbon accumulation capacity of the two species; this demonstrates the vulnerability of these ecosystems to global warming and environmental changes in northern Mexico.

The application of allometric equations associated with wood density and its response to climatic variability constitutes a reliable methodology that allows for the understanding of the variability in carbon accumulation under specific climatic conditions (Pompa-García \& VenegasGonzález, 2016). This approach offers a temporal perspective of carbon accumulation and allows 
291 us to appreciate the intra-annual variation in woody biomass and consequently the carbon content

292 (Pompa-García et al., 2018).

The inclusion of wood density as an indicator of climate variability improves the carbon capture estimates. Several studies carried out in the area have evaluated the responses to climatic conditions (González-Elizondo et al., 2005; González-Cásares, Pompa-García \& Camarero, 2017; Pompa-García et al., 2017a), while others have used density for biometric purposes (GonzálezCásares, Yerena-Yamallel \& Pompa-García, 2016; Pompa-García \& Venegas-González, 2016). It has also been reported that the wood density of a species (Abies durangensis) that coexists with the species evaluated in the present study is more sensitive to temperature than the tree-ring width (González-Cásares, Pompa-García \& Venegas-González, 2018). In this study, density was used to improve the estimation of carbon capture and its response to climate and thus facilitate a reliable 302 and valuable comparative analysis to broaden the knowledge of the carbon accumulation in forest ecosystems.

The ring width of $P$. menziesii was positively correlated with the precipitation from the previous winter through March of the current year. Precipitation during the cold season positively affects tree growth because it recharges the soil water and triggers tree growth (Pompa-García \& Venegas-González, 2016), while it also improves the photosynthetic activity of trees during the early growth season (Kerhoulas, Kolb \& Koch, 2013). These results are consistent with those obtained for other conifers from nearby regions (Carlón-Allende et al., 2018, Cleaveland et al., 2003; González-Elizondo et al., 2005; Pompa-García \& Camarero, 2015; Pompa-García \&

311 Venegas-González, 2016). The RW and MXD values of $P$. menziesii showed a negative response

312 to temperature, which is consistent with the results of another study in the region that reported a 313 negative correlation between maximum temperature and WD in Pinus cooperi (Pompa-García \& 
314 Venegas-González, 2016). This result could be attributed to the fact that the wood density of some

315 conifers of the Sierra Madre Occidental is sensitive to high temperatures, which increases the cell

316 wall thickness of the tracheids of latewood. In contrast, temperature has a positive influence on

317 the MeanD and MND of C. lusitanica but not on the tree-ring width, which suggests that

318 temperature controls the size of the cell (the lumen and the cell wall of the tracheids) but not the

319 quantity (Thomas, Montagu \& Conroy, 2007). In this species, it should be noted that the carbon

320 accumulation is more associated with ring width than wood density (Figure 7).

There is evidence that the increase in the global mean temperature is causing increased tree

322 mortality due in water stress and attack by biotic agents (Allen, Breshears \& McDowell, 2015).

323 We observed a variation in carbon accumulation between the two species (Figure 6a), that could

324 be attributed to an increase in mean temperature and a decrease in rainfall in the region since 1980

325 (Figure 6d, CNA, 2016). For P. menziesii, results showed that ring width and maximum density

326 are negatively affected by temperature (Figure 5). In addition, a high association with carbon

327 accumulation was observed with mean wood density, which is strongly related to the rainfall

328 during the cold season (Figure 7a). All these findings would be affecting the growth of this species

329 in northern Mexico. In western North America, an outstanding increase in mortality triggered by

330 drought and high temperatures has been documented in P. menziesii, (Bentz et al., 2009).

In contrast for $C$. lusitanica, we observed a positive correlation with mean temperature that

332 would positively affect carbon accumulation, especially during the fall (September-November)

333 (Figure 5a, 7b). A recent study found that tree growth of this species increased with temperature

334 and did not seem respond to negatively to drought. Hence, it could be potentially favored with

335 projections of global warming (Pompa-García, Sánchez-Salguero \& Camarero, 2017). However,

336 in other conifers from wet sites, if they are drought sensitivity and would be affected by the 
337 increase in temperatures by 2100 (González-Cásares, Pompa-García \& Camarero, 2017; Pompa-

338 García, Sánchez-Salguero \& Camarero, 2017), so we believe that the response to climate varies

339 between species.

340 As climate change progresses, there is evidence of global temperature increases being

341 linked to an increasing frequency and duration of drought throughout much of the world (IPCC,

342 2013). The predicted climate changes are represented as an increase in the global average

343 temperature, with an increase in aridity in some areas as well as in the frequency and severity of

344 extreme droughts (Allen et al., 2010). In the projections of changes in vegetation caused by climate

345 change, tree mortality becomes a central issue (Allen, Breshears \& McDowell, 2015). When

346 studying carbon capture in forests, it is important to have a general perspective on the effects of

347 the climate on these ecosystems.

348 Combined with other methods, the calculation of biomass using growth rings provides

349 more accurate estimations of carbon capture and improves the temporal resolution of periodic

350 forest inventories (Babst et al., 2014c). The use of wood density for estimating biomass improves

351 our understanding of the dynamics of carbon capture in these ecosystems (González-Cásares,

352 Yerena-Yamallel \& Pompa-García, 2016; Pompa-García \& Venegas-González, 2016; Pompa-

353 García et al., 2018). In general, the results show that low precipitation and high temperatures lead

354 to substantial effect on carbon accumulation over the last 30 years. The increase in the mean annual

355 temperature in the study area (CNA, 2016) that has taken place over the last years seems to have

356 had a positive impact on carbon accumulation in some tree species, such as Cupressus lusitanica.

357 Moreover, the negative trends of annual precipitation will cause reduced carbon uptake in some 358 species, such as Pseudotsuga menziesii (Figure 6d).

359 5. Conclusion 
361 accumulation. This difference is attributed to the specific responses of each species to climatic

362 conditions. C. lusitanica and P. menziesii showed different responses to seasonal climatic

363 variability. In general, the carbon accumulation of $P$. menziesii responded significantly to the

364 precipitation during the previous winter, while the temperature of the autumn season influenced

365 carbon sequestration by $C$. lusitanica. In this sense, the negative and positive trends in precipitation

366 and temperature in this region have caused negative and positive carbon accumulation trends in $P$.

367 menziesii and C. lusitanica, respectively. The results of this study provide a basis for modeling the

368 long-term carbon budget projections in terrestrial ecosystems in northern Mexico. Therefore, these

369 results are of value for the evaluation of dynamic models of the global carbon balance.

370 Acknowledgments

371 Thanks as well to the community known as "Ejido el Brillante" and to the forester

372 responsible for the area (Dr. Javier Bretado), for the support provided for data collection. We thank

373 the Dirección General de Vida Silvestre, SEMARNAT (Secretaría de Medio Ambiente y Recursos

374 Naturales, Mexico), for facilitating field sampling. We thank Mario Tomazello Filho and Alci

375 Albiero Junior for their support in preparation of samples and x-ray densitometry analysis. We

376 also thank two other anonymous reviewers for their critical and useful comments.

377 6. References

378 Acosta-Hernández AC, Pompa-García M, Camarero JJ. 2017. An updated review of 379 dendrochronological investigations in Mexico, a megadiverse country with a high potential 380 for tree-ring sciences. Forests 8. DOI:10.3390/ f8050160. 
381 Aguirre-Díaz GJ, Labarthe-Hernández G. 2003. Fissure ignimbrites: Fissure-source origin for 382 voluminous ignimbrites of the Sierra Madre Occidental and its relationship with Basin and $383 \quad$ Range faulting Geology 31: 773-776.

384

385

386

387

388

389

390

391

392

393

Allen CD, Macalady AK, Chenchouni H, Bachelet D, McDowell N, Vennetier M, Kitzberger T, Rigling A, Breshears DD, Hogg EH, Gonzalez P, Fensham R, Zhang Z, Castro J, Demidova N, Lim JH, Allard G, Running SW, Semerci A, Cobb N. 2010. A global overview of drought and heat-induced tree mortality reveals emerging climate change risks for forests. Forest Ecology and Management 259(4):660-684 DOI: 10.1016/j.foreco.2009.09.001.

Allen CD, Breshears DD, McDowell NG. 2015. On underestimation of global vulnerability to tree mortality and forest die-o $\square$ from hotter drought in the Anthropocene. Ecosphere 6(129):1-55 DOI: 10.1890/ES15-00203.1.

Babst F, Alexander MR, Szejner P, Bouriaud O, Klesse S, Roden J, Ciais P, Poulter B, Frank D, Moore DJP. 2014a. A tree-ring perspective on the terrestrial carbon cycle. Oecologia 176: 307-322. DOI: 10.1007/s00442-014-3031-6.

Babst F, Bouriaud O, Papale D, Gielen B, Janssens IA, Nikinmaa E, Ibrom A, Wu J, Bernhofer C, Köstner B. 2014b. Aboveground woody carbon sequestration measured from tree rings is coherent with net ecosystem productivity at five eddy covariance sites. New Phytologist 201: 1289-1303 DOI: 10.1111/nph.12589.

Babst F, Bouriaud O, Alexander R, Trouet V, Frank D. 2014c. Toward consistent measurements of carbon accumulation: A multi-site assessment of biomass and basal area increment across Europe. Dendrochronologia 32: 153-161 DOI: 10.1016/j.dendro.2014.01.002. 
402 Bentz BJ, Allen CD, Ayres M, Berg E, Carroll A, Hansen M, Hicke J, Joyce L, Logan J, 403 MacFarlane W, MacMahon J, Munson S, Negron J, Paine T, Powell J, Raffa K, Régnière J, 404 Reid M, Romme W, Seybold S, Six D, Tomback D,Vandygriff J, Veblen T, White M, 405 Witcosky J, Wood D. 2009. In: Bentz BJ (Ed.) Bark Beetle Outbreaks in Western North 406 America: Causes and Consequences. Univ. of Utah Press.

407 Bigler C, Gavin DG, Gunning C, Veblen TT. 2007. Drought induces lagged tree mortality in a 408 subalpine forest in the Rocky Mountains. Oikos 116:1983-1994 DOI: 10.1111/j.2007.0030$409 \quad$ 1299.16034.x.

410 Bunn AG. 2008. A dendrochronology program library in R (dplR). Dendrochronologia 26: 115411 DOI:10.1016/j.dendro.2008.01.002.

412 Carlón-Allende T, Villanueva-Díaz J, Mendoza ME, Pérez-Salicrup DR. 2018. Climatic signal in 413 earlywood and latewood in conifer forests in the Monarch Butterfly Biosphere Reserve, 414 Mexico. Tree-ring research 74(1): 63-75 DOI: 10.3959/1536-1098-74.1.63.

415 Cerano PJ, Villanueva DJ, Valdez CRD, Méndez GJ, Constante GV. 2011. Sequías reconstruidas 416 en los últimos 600 años para el noreste de México. Revista Mexicana de Ciencias Agrícolas $417 \quad 2: 235-249$.

418 Cleaveland MK, Stahle DW, Therrell MD, Villanueva-Diaz J, Burns BT. 2003. Tree-ring 419 reconstructed winter precipitation and tropical teleconnections in Durango, Mexico. Climatic 420 Change 59:369-388 DOI: 10.1023/A:1024835630188.

421 Comisión Nacional del Agua (CNA). 2016. Datos Climáticos de Estaciones Meteorológicas de 422 Durango: El Salto. México, 2016. Available online: 

http://smn1.conagua.gob.mx/index.php?option=com_content\&view=article\&id=180:durang o\&catid=14:normales-por-estacion (accessed 10 February 2017).

425 426

Cook E. 1985. A time series analysis approach to tree ring standardization. Lamont-Doherty Geol. Obs. University of Arizona.

Cuny HE, Rathgeber CBK, Frank D, Fonti P, Mäkinen H, Prislan P, Rossi S, del Castillo EM, Campelo F, Vavrčík H, Camarero JJ, Bryukhanova MV, Jyske T, Gričar J, Gryc V, De Luis M, Vieira J, Čufar K, Kirdyanov AV, Oberhuber W, Treml V, Huang JG, Li X, Swidrak I, Deslauriers A, Liang E, Nöjd P, Gruber A, Nabais C, Morin H, Krause C, King G, Fournier M. 2015. Woody biomass production lags stem-girth increase by over one month in coniferous forests. Nature Plants 1:15160 DOI: 10.1038/nplants.2015.160.

Dong J, Kaufmann RK, Myneni RB, Tucker CJ, Pekka EK, Liski J, Buermann W, Alexeyev V, Hughes MK. 2003. Remote sensing estimates of boreal and temperate forest woody biomass: carbon pools, sources, and sinks. Remote Sensing of Environment 84(3):393-410.

González-Cásares M, Pompa-García M, Camarero JJ. 2017. Differences in climate-growth relationship indicate diverse drought tolerances among five pine species coexisting in Northwestern Mexico. Trees 31(2):531-544 DOI: 10.1007/s00468-016-1488-0.

González-Cásares M, Pompa García M, Venegas González A. 2018. Climate signals from intraannual wood density fluctuations in Abies durangensis. IAWA Journal 00(0): 1-12. DOI $10.1163 / 22941932-40190217$.

González-Cásares M, Yerena-Yamallel JI, Pompa-García M. 2016. Measuring temporal wood density variation improves carbon capture estimates in Mexican forests. Acta Universitaria 26: 11-14 DOI: 10.15174/au.2016.1206. 
445 González-Elizondo M, Jurado E, Návar J, González-Elizondo MS, Villanueva J, Aguirre O, 446 Jiménez J. 2005. Tree-rings and climate relationships for Douglas-fir chronologies from the 447 Sierra Madre Occidental, Mexico: a 1681-2001 rain reconstruction. Forest Ecology and 448 Management 213:39-53 DOI: 10.1016/j.foreco.2005.03.012.

449 González-Elizondo MS, González-Elizondo M, Tena-Flores JA, Ruacho-González L, López450 Enríquez IL. 2012. Vegetación de la sierra madre occidental, México: Una síntesis. Acta 451 botánica Mexicana 100:351-403.

Grissino-Mayer HD. 2001. Evaluating Crossdating Accuracy: A Manual and Tutorial for the 453 Computer Program COFECHA. Tree-Ring Research. 57:205-221.

Holmes RL. 1983. Computer-assisted quality control in tree-ring dating and measurement. Tree 455 Ring Bulletin 43:69-78.

456

457 458

460

461

462

463

464

465

466

Houghton RA. 2005. Aboveground forest biomass and the global carbon balance. Global change biology 11:945-958 DOI: 10.1111/j.1365-2486.2005.00955.x.

Huang JG, Bergeron Y, Denneler B, Berninger F, Tardif J. 2007. Response of forest trees to increased atmospheric CO2. Critical Reviews in Plant Sciences 26:265-283 DOI: $10.1080 / 07352680701626978$.

Intergovernmental Panel on Climate Change (IPCC). 2013. Summary for Policymakers. In Climate Change 2013: The Physical Science Basis. Cambridge University Press: Cambridge, UK; New York, NY, USA.

Kerhoulas LP, Kolb TE, Koch GW. 2013. Tree size, stand density, and the source of water used across seasons by ponderosa pine in northern Arizona. Forest Ecology and Management 289:425-433 DOI: 10.1016/j.foreco.2012.10.036. 
467 Návar J. 2009. Allometric equations for tree species and carbon stocks for forests of northwestern 468 Mexico. Forest Ecology and Management 257:427-434 DOI: 10.1016/j.foreco.2008.09.028.

469 Pan, Y., Birdsey, R.A., Fang, J., Houghton, R., Kauppi, P.E., Kurz, W.A., Phillips, O.L., 470 Shvidenko, A., Lewis, S.L., Canadell, J.G., 2011. A large and persistent carbon sink in the $471 \quad$ world's forests. Science (80-. ). 333, 988-993.

472 Périé C, De Blois S. 2016. Dominant forest tree species are potentially vulnerable to climate 473 change over large portions of their range even at high latitudes. PeerJ 4:e2218 DOI: 474 $10.7717 /$ peerj. 2218

475

476

477

478

479

480

481

482

483

484

485

486

Pompa-García M, Camarero JJ. 2015. Reconstructing Evaporation From Pine Tree Rings In Northern Mexico. Tree-Ring Research. 71:95-105 DOI: 10.3959/1536-1098-71.2.95.

Pompa-García M, Venegas-González A. 2016. Temporal Variation of Wood Density and Carbon in Two Elevational Sites of Pinus cooperi in Relation to Climate Response in Northern Mexico. PLoS One 11(6): e0156782 DOI: 10.1371/journal.pone.0156782.

Pompa-García, M., Sánchez-Salguero, R., \& Camarero, J. J. 2017. Observed and projected impacts of climate on radial growth of three endangered conifers in northern Mexico indicate high vulnerability of drought-sensitive species from mesic habitats. Dendrochronologia (45): 145155.

Pompa-García M, González-Cásares M, Acosta-Hernández AC, Camarero JJ, Rodríguez-Catón M. 2017a. Drought Influence over Radial Growth of Mexican Conifers Inhabiting Mesic and Xeric Sites. Forests 8:175 DOI: 10.3390/f8050175. 
487 Pompa-Garcia, M., Sigala-Rodríguez, J. A., Jurado, E., \& Flores, J. 2017b. Tissue carbon 488 concentration of 175 Mexican forest species. iForest-Biogeosciences and Forestry 10(4): 489754.

490 Pompa-García M, Venegas-González A, Albiero Junior A, Sigala-Rodríguez JA. 2018. 491 Dendroecological approach to assessing carbon accumulation dynamics in two Pinus species 492 from northern Mexico. Tree-Ring Research 74(2):196-209.

493 R Development Core Team. 2015. R: A Language and Environment for Statistical Computing; R $494 \quad$ Foundation for Statistical Computing: Vienna, Austria.

495 Sánchez-Salguero R, Navarro RM, Camarero JJ, Fernández-Cancio Á. 2010. Drought-induced 496 growth decline of Aleppo and maritime pine forests in south-eastern Spain. Forest Systems 19:458-470 DOI: 10.5424/fs/2010193-9131.

Taki S, Nobori Y, Caceres MLL. 2014. Method for estimation of stem carbon fixation of Japanese black pine by combining stem analysis and soft X-ray densitometry. Journal of forest research 19(1): 226-232.

Thomas DS, Montagu KD, Conroy JP. 2007. Temperature effects on wood anatomy, wood density, 502 photosynthesis and biomass partitioning of Eucalyptus grandis seedlings. Tree Physiology 503 27(2):251-260.

504 Tomazello M, Brazolin S, Chagas MP, Oliveira JTS, Ballarin AW, Benjamin CA. 2008. 505 Application of X-ray technique in nondestructive evaluation of eucalypt wood. Maderas. 506 Ciencia y Tecnología 10:139-149 DOI: 10.4067/S0718-221X2008000200006. 
507 Venegas-González, A., Juñent, F. R., Gutiérrez, A. G., \& Tomazello Filho, M. 2018. Recent radial

508 growth decline in response to increased drought conditions in the northernmost Nothofagus

509 populations from South America. Forest Ecology and Management 409: 94-104.

510 Villanueva D J, Cerano P J, Constante G V, Stahle DW, Estrada Á J, Tostado P MM. Variabilidad

511 hidroclimática histórica del norte de México inferida con anillos de crecimiento de douglas-

512 fir. Revista Mexicana de Ciencias Agrícolas 2: 221-234.

513 Yerena-Yamallel JI, Jiménez PJ, Aguirre COA, Treviño GEJ, Alanís RE. 2012. Concentración de

514 carbono en el fuste de 21 especies de coníferas del noreste de México. Revista Mexicana de

$515 \quad$ Ciencias Forestales 3:49-56.

516 Zar JH. 2010. Biostatistical analysis 5th edition. Pearson Prentice-Hall, Upper Saddle River, NJ.

517 Wigley TML, Briffa KR, Jones PD. 1984. On the average value of correlated time-series, with 518 applications in dendroclimatology and hydrometeorology. Journal of Applied Meteorology 519 and Climatology 23:201-213 DOI:10.1175/1520-0450(1984)023<0201:otavoc $>2.0 . c 0 ; 2$

520 Zeppel MJB, Anderegg WRL, Adams HD. 2012. Forest mortality due to drought: latest insights, 521 evidence and unresolved questions on physiological pathways and consequences of tree 522 death. New Phytologist 197(2):372-374 DOI: 10.1111/nph.12090. 
Figure 1

Study site location and local climate diagram.

(a) The map shows the study area where Cupressus lusitanica and Pseudotsuga menziesii trees were sampled. $(\mathbf{b}, \mathbf{c})$ The climate diagrams illustrate the distribution of monthly precipitation (P) and mean temperature (T) for the time period 1946-2015 (El Salto meteorological station; located at coordinates $23^{\circ} 41^{\prime} 25^{\prime \prime},-105^{\circ} 21^{\prime} 10^{\prime \prime}$, at an altitude of $2,538 \mathrm{~m})$.

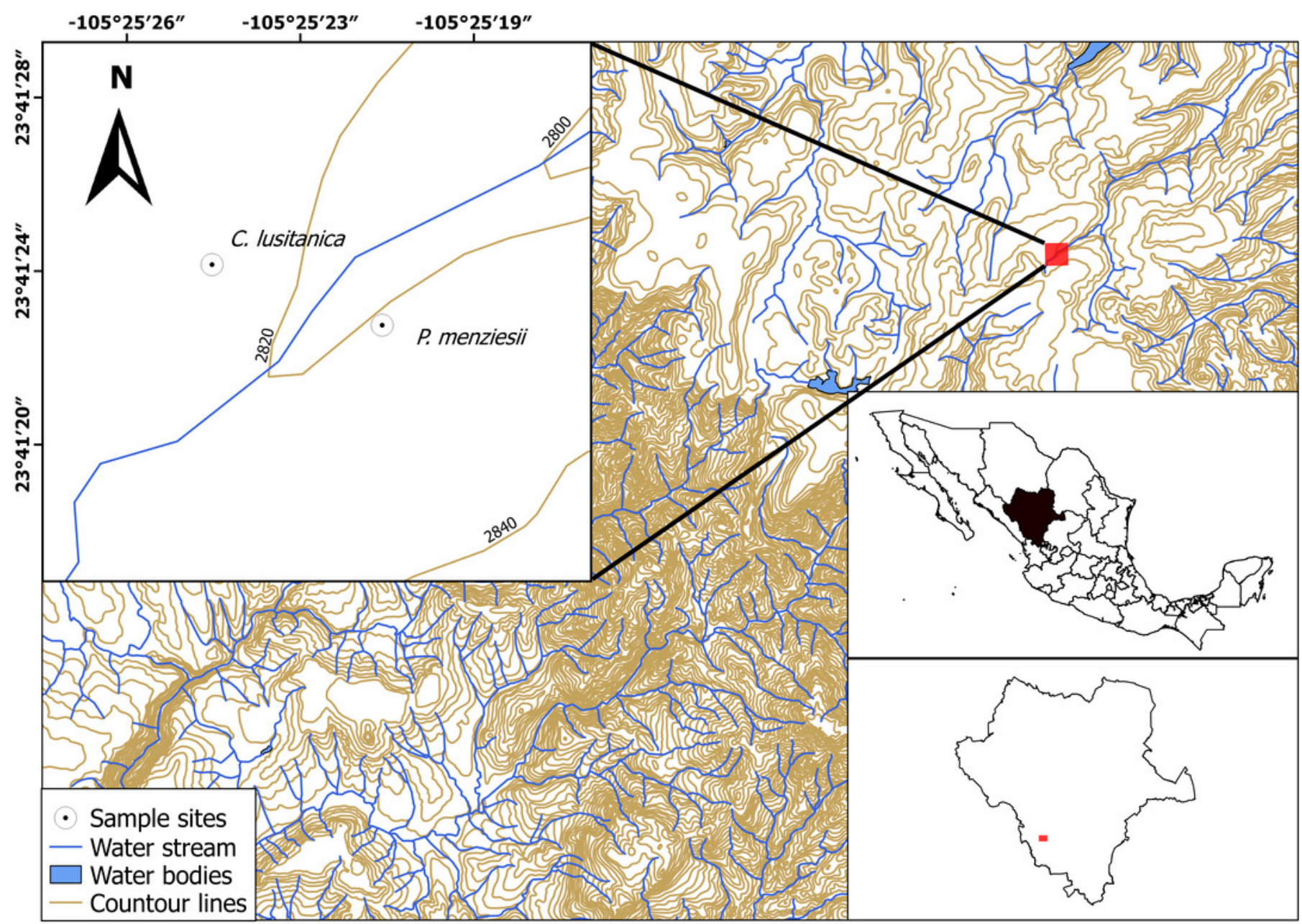


Figure 2

Tree-ring chronologies of the two study species

Residual chronologies (black lines) and series (gray lines) of ring widths of the two study species for the best cross-dated period. (a) Cupressus lusitanica, (b) Pseudotsuga menziesii. 

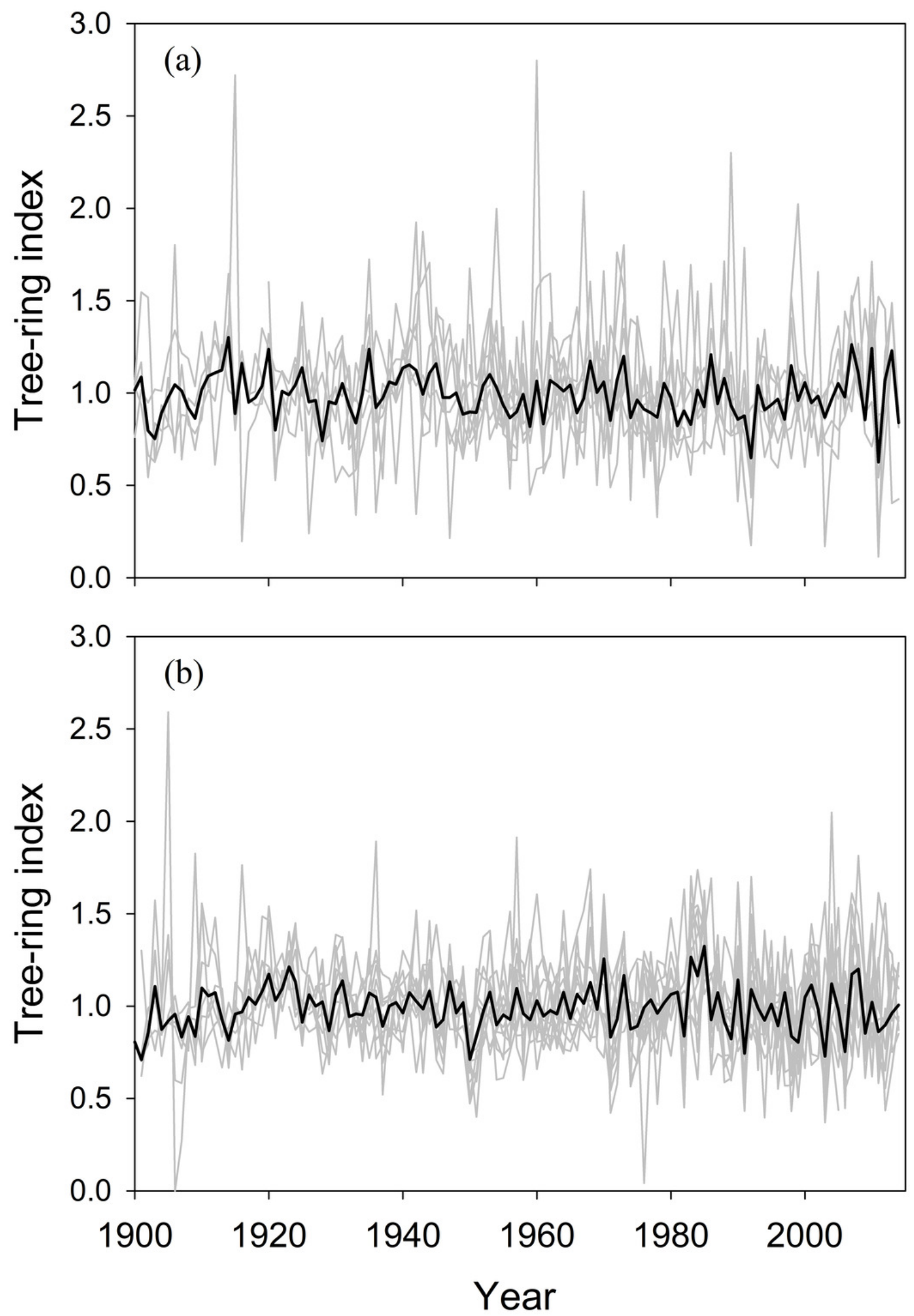
Figure 3

Mean values of wood density of the two study species

Mean \pm SE values of maximum density (MXD), minimum density (MND), and mean density (MeanD) of the two study species, for the period 1920-2014 (five trees per species). Positive $(+)$ and negative (-) trends of density values are shown in right graphics. (a,b) Cupressus lusitanica, (c,d) Pseudotsuga menziesii.

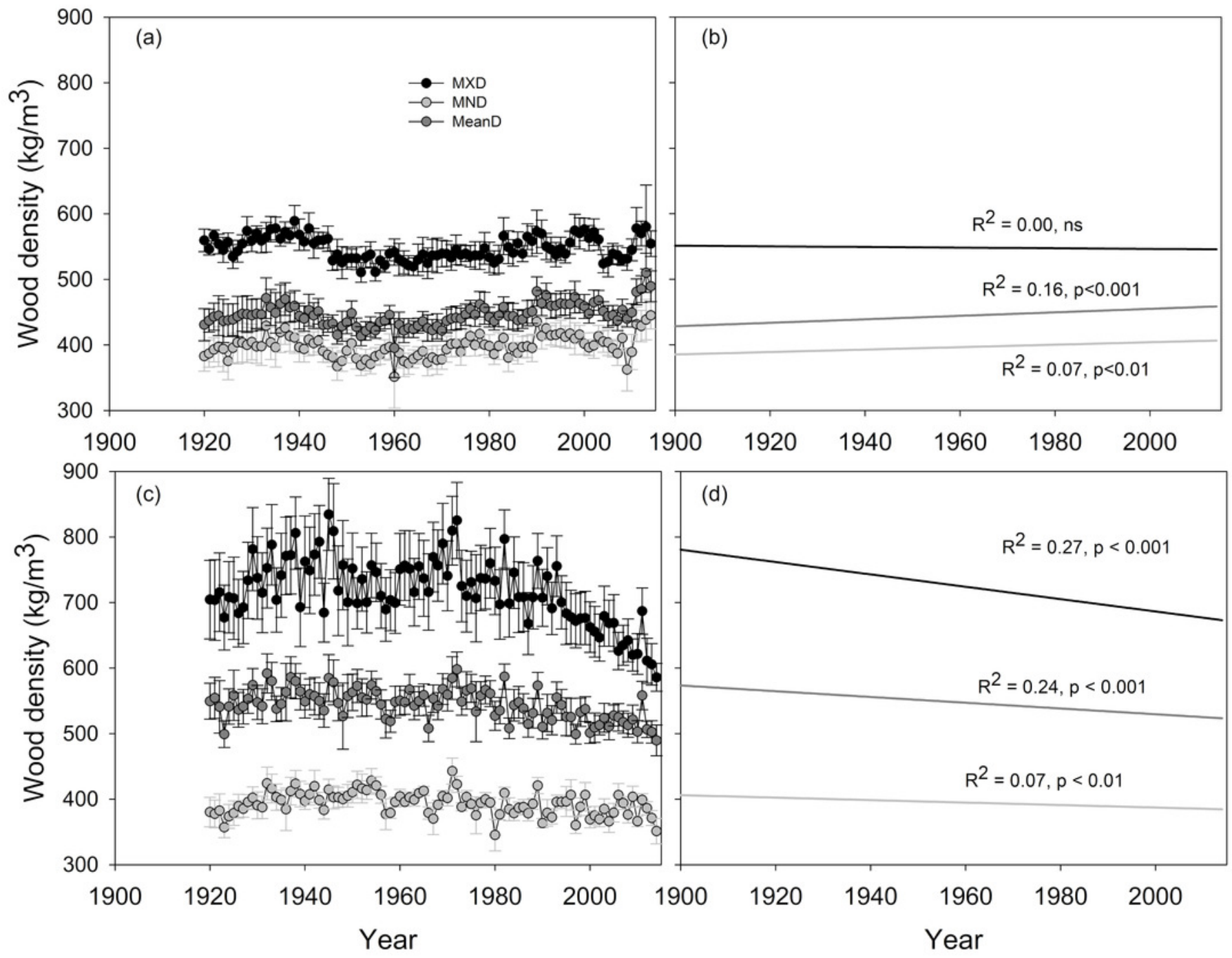




\section{Figure 4}

Relationships between residual chronologies (growth ring width (RW), maximum density (MXD), minimum density (MND), and mean density (MeanD) and accumulated precipitation.

The left and right columns represent the analysis by month and by season, respectively; that is, summer, fall, winter, spring, annual, and cold (October-April). Letters indicate growth periods ( $\mathrm{PY}$ and lowercase $=$ previous year, $\mathrm{CY}$ and uppercase $=$ current year). Dashed horizontal lines indicate statistical significance at the 95\% confidence level. (a) Cupressus lusitanica, (b) Pseudotsuga menziesii. 


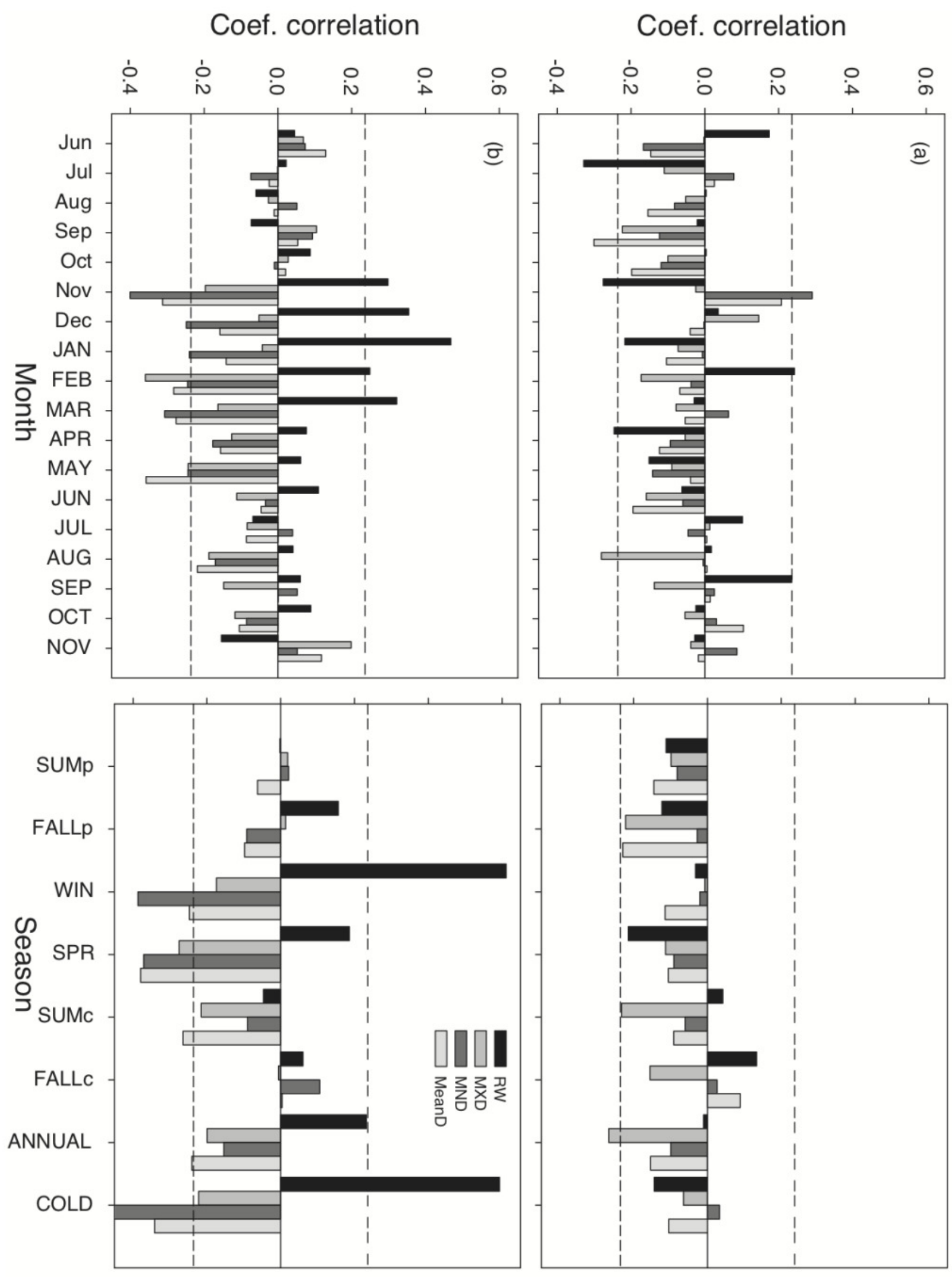




\section{Figure 5}

Relationships between residual chronologies (growth ring width (RW), maximum density (MXD), minimum density (MND) and mean density (MeanD)) and mean temperature.

The left and right columns represent analysis by month and by season, respectively; that is, summer, fall, winter, spring, annual, and cold (October-April). Letters indicate growth periods (PY and lowercase $=$ previous year, $\mathrm{CY}$ and uppercase $=$ current year). Dashed horizontal lines indicate statistical significance at the $95 \%$ confidence level. (a) Cupressus lusitanica, (b) Pseudotsuga menziesii. 


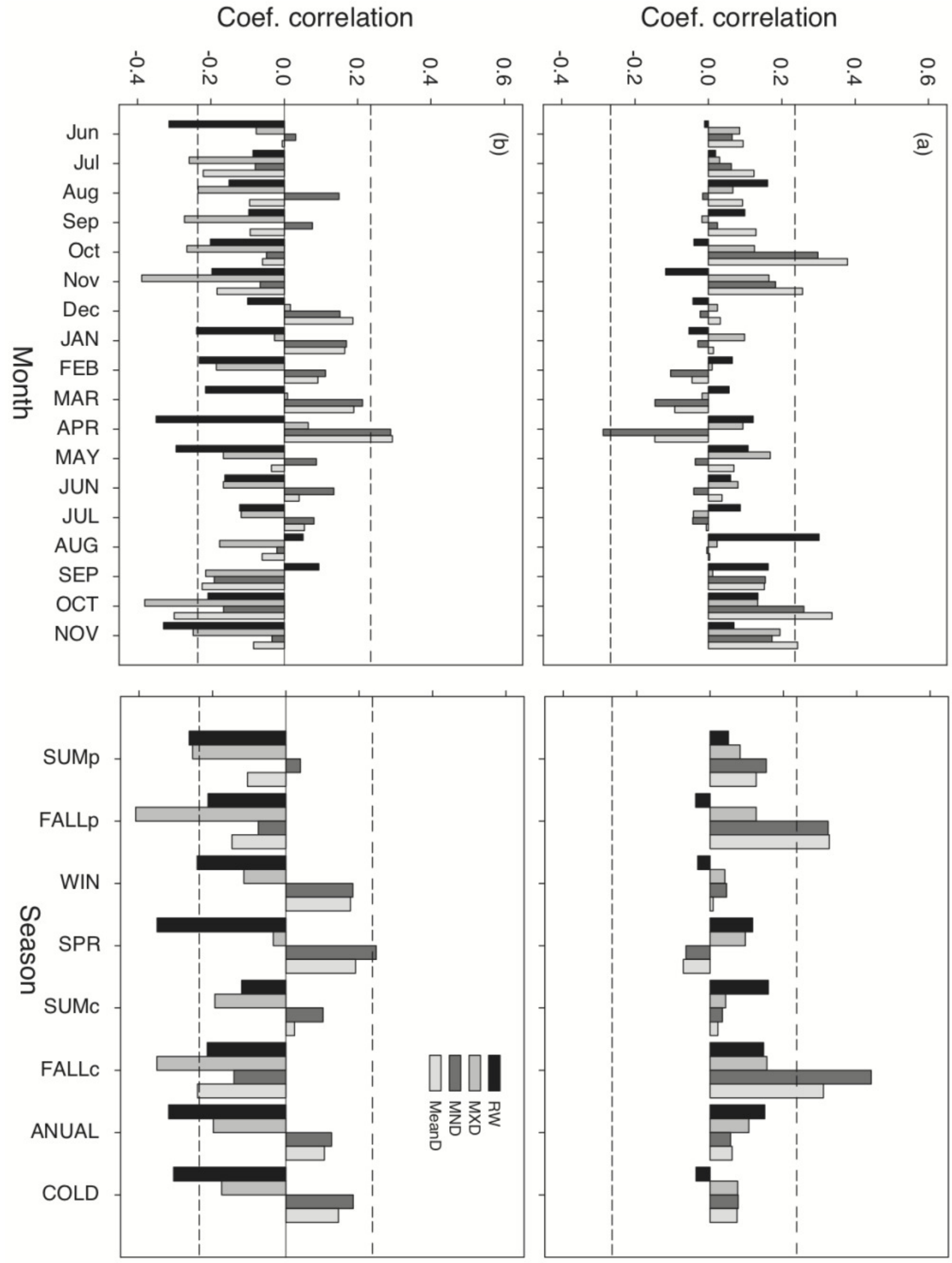


Figure 6

Temporal variation of carbon capture

(a) Carbon accumulation per year in the two studied conifers. Gray lines indicate the standard error. (b) Relationship between carbon accumulation per year and ring width in Cupressus lusitanica. (c) Relationship between carbon accumulation per year and mean wood density in Pseudotsuga Menziesii. (d) Data trend of mean annual temperature and total precipitation per year
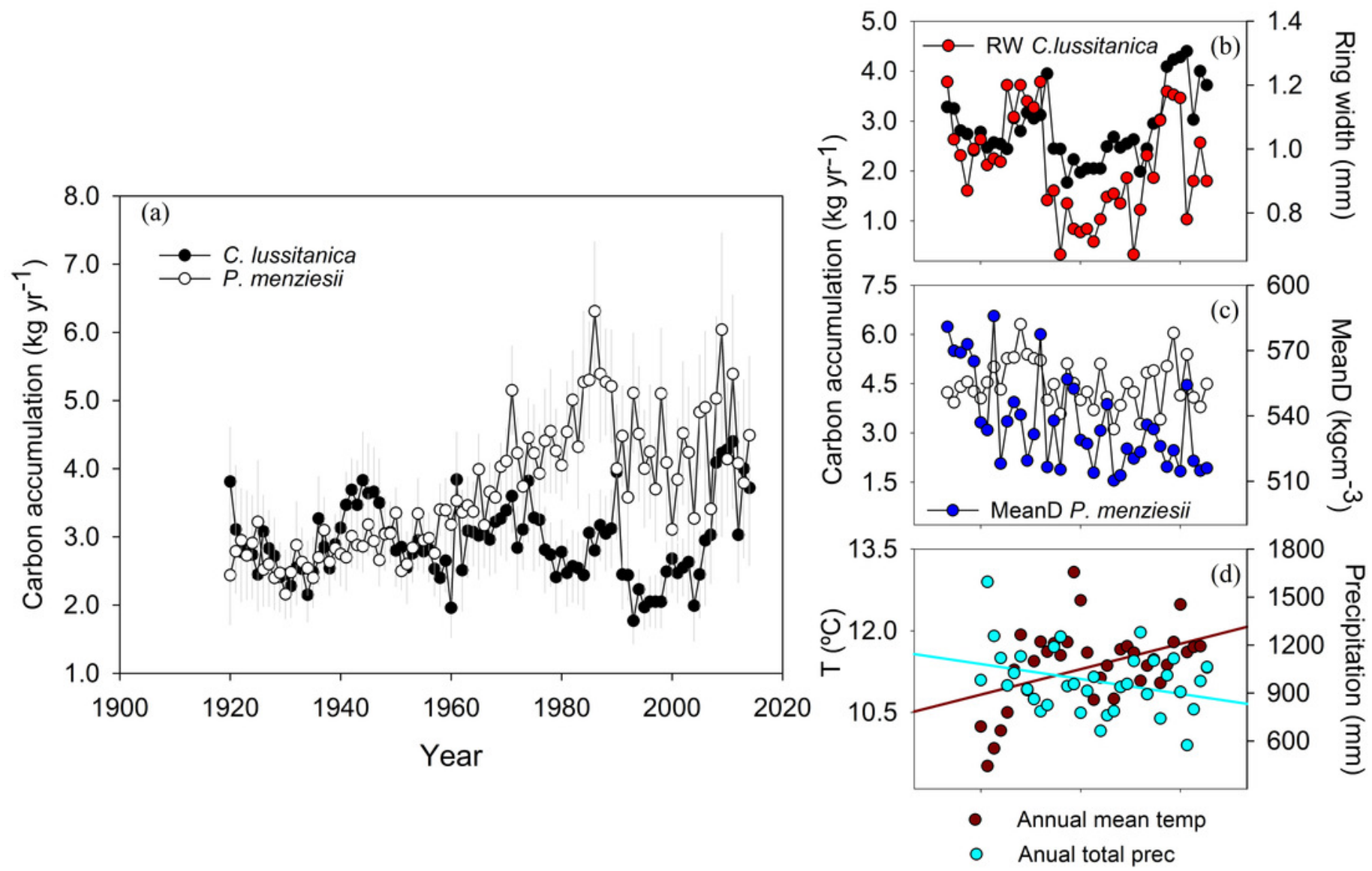


\section{Figure 7}

Principal component analysis between carbon capture and internal influences (radial growth and wood density variables) and seasonal climatic influences (precipitation and temperature) for 1975-2014

The yellow, green, blue and red circles indicate radial growth, the wood density variables, the precipitation variables, and the temperature variables, respectively. Win $=$ winter, Fall $=$ autumn, Spr = spring, Sum = summer. The dashed circle represents the maximum correlation with carbon accumulation. (a) Cupressus lusitanica (copheneticcorrelation = 0.79), (b) Pseudotsuga menziesii (copheneticcorrelation $=0.81$ ). 


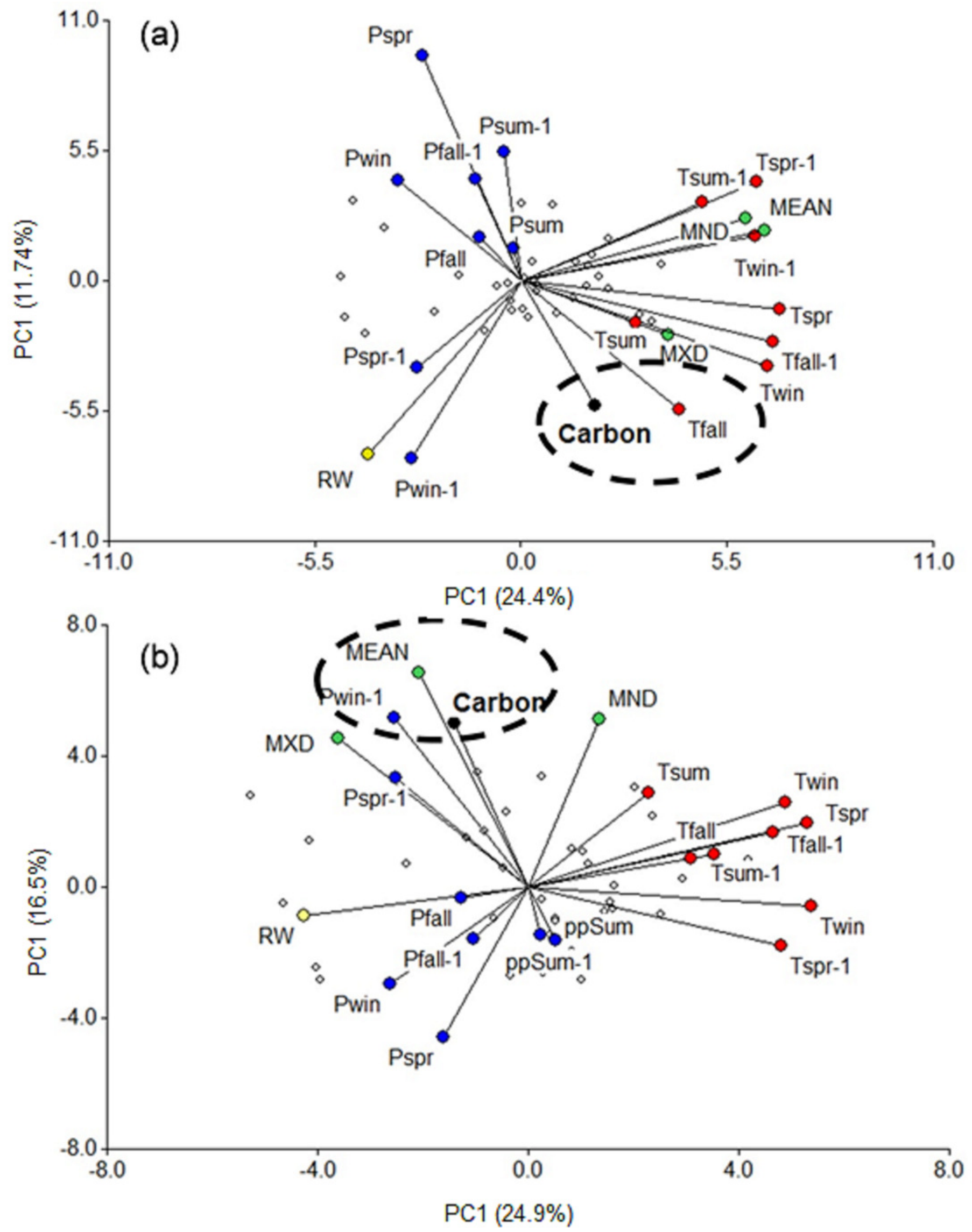




\section{Table 1 (on next page)}

Descriptive statistics of chronologies

Time span (TS), mean sensitivity (MS), expressed signal of the population (EPS), density

(WD), carbon accumulation (C). 
1 Table 1. Characteristics of the species studied. Period of time (TS), mean sensitivity (MS), 2 expressed signal of the population (EPS), density (WD), carbon accumulation (C).

3

\begin{tabular}{cccccccc}
\hline Species & Trees (Cores) & TS & MS* & EPS & RW & WD (Kg m $\left.\mathbf{~}^{-3}\right)$ & C (Kg $\left.\mathbf{~ y r}^{-1}\right)$ \\
\hline C. lusitanica & $15(12)$ & $1855-2014$ & 0.25 & 0.78 & $1.24 \pm 0.35$ & $462.3 \pm 0.45(\mathrm{a})$ & $2.2 \pm 0.13(\mathrm{a})$ \\
& & & & & & & \\
P. menziesii & $14(13)$ & $1901-2014$ & 0.25 & 0.89 & $1.58 \pm 0.33$ & $550.5 \pm 0.78(\mathrm{~b})$ & $3.7 \pm 0.24(\mathrm{~b})$
\end{tabular}

4 Values are annual means \pm SE. Means sharing a letter were not significantly different $(\mathrm{p}<0.05)$ using a Mann-

5 Whitney-Wilcoxon test. RW did not show significant differences

6

7 
